\title{
Selection of Arteries for Blood Sampling and Evaluation of Blood Gases and Acid-Base Balance in Cattle
}

\author{
O. NAGY, G. KOVÁČ, H. SEIDEL, I. PAULÍKOVÁ
}

Department of Internal Diseases of Ruminants and Swine, University of Veterinary Medicine, Košice, Slovak Republic

Received January 7, 2002

Accepted June 19, 2002

\begin{abstract}
Nagy O., G. Kováč, H. Seidel, I. Paulíková: Selection of Arteries for Blood Sampling and Evaluation of Blood Gases and Acid-Base Balance in Cattle. Acta Vet. Brno 2002, 71: 289-296.

The aim of this work was to select the most useful arteries for blood sampling in calves and cows in relation to the evaluation of acid-base balance and blood gases in cattle. Following the anatomy and literature data, we chose six central and peripheral arteries - a. axillaris, a. carotis communis, a. brachialis, a. saphena, a. caudalis mediana, and a. auricularis caudalis. The blood samples were collected from 152 calves ( 2 weeks-6 months old) and 51 dairy cows. The efficiency of collection was evaluated with emphasis on minimizing the restraining and stressing of the animals, because of the possible effects of the animals' responses on blood gases values. In both categories, the results showed that the most convenient and reliable sampling sites were $a$. axillaris and $a$. auricularis caudalis. Both in calves and cows, punctures of a. carotis communis and a. caudalis mediana were less successful because of more demanding restraint, the stronger responses of the animals, and the less repeatibility of the sampling, resp. The least efficiency was recorded for the punctures of $a$. brachialis and $a$. saphena. Moreover, in these punctures, the difficult restraint of calves in the lateral position may lead to significant changes in the examined indices.

Cattle, arterial blood, blood collection, acid-base balance, blood gases
\end{abstract}

Collection and examination of blood are frequent operations within the complex of clinical and laboratory diagnosis of health disorders in animals. Venous blood is collected the most frequently; collection of arterial or arterialized capillary blood is less frequent. Some authors used arterial blood for the investigation of arterio-venous differences in the concentrations of some metabolites (Björkman et al. 1992; Gallagher et al. 1997; Mudroň et al. 1999). However, in clinical practice, the analysis of arterial blood is particularly important in evaluating the acid-base balance (ABB) and blood gases (BG). The analysis of arterial blood has a special position in the pathogenesis and diagnosis of respiratory diseases, the pathogenesis of intoxications, anaemias, and various diseases exerting primary or secondary effects on blood gases values, and the saturation of haemoglobin with oxygen. Information on oxygenation, ventilation, as well as on metabolic acid-base disorders in peripartal period obtained by analysis of blood gases in the arterial blood represents a practical example of the use of arterial blood in calves (Adams et al. 1991). Examination of venous blood does not yield complete information on the respiratory functions (S peirs 1980). Wide use of collection and analysis of arterial blood was hampered mostly by the costs of laboratory equipment needed to analyse ABB and BG. Advances in analytical technologies, acceptable prices and user-friendly instruments create opportunities for the wider use of arterial blood analyses both in veterinary practice and research activities (Collie 1991). In calves and adult cattle, several possible sites of arterial blood collection are described (Slanina et al. 1992; Mudroň 1998; Nagy et al. 2001). Moreover, these works do not describe almost any experiences and opinions about the advantages, disadvantages, and/or convenience and reliability of the collection techniques, especially in relation to the collection site.

Address for correspondence:

MVDr. Oskar Nagy, PhD.

Department of Internal Diseases of Ruminants and Swine

University of Veterinary Medicine
Komenského 73, 041 81 Košice, Slovak Republic
Phone: +421556338071

Fax: +421 556323666

http://www.vfu.cz/acta-vet/actavet.htm 
This work evaluates some puncture sites of arterial blood collection in calves and adult dairy cows. The aim of the work was the selection of the most useful puncture sites and techniques for blood collection from central and peripheral arteries. Attention was paid to the restraint of the animals to avoid their stressing with consequent changes in the indices under study.

Animals

\section{Materials and Methods}

The punctures of arteries and collection of arterial blood were done in 152 calves ( 2 weeks-6-month-old) and in 51 dairy cows (Slovak spotted, Holstein-Friesian, and their crossbreds). Besides clinically healthy animals, we used also patients from our clinic.

Selection of arteries to be punctured

Following the anatomy and literature data we chose the following arteries - a. axillaris, a. carotis communis, a. brachialis, a. saphena, a. caudalis mediana, and $a$. auricularis caudalis. The selection criterion was the puncture of the artery directly without surgical interventions (insertion of cannula, subcutaneous relocation of the artery) and without sedation.

Puncture of a. carotis communis was done on standing animals at the middle and bottom third of the neck. Because the artery is located deeper below the skin, running mediodorsally to the jugular vein, the needle was inserted above the jugular vein, perpendicularly to the neck, to the depth of $2-3 \mathrm{~cm}$.

A. axillaris was punctured at the base of neck at the beginning of jugular groove. At this point, the artery is leaving the thoracic cavity, turning around the $1 \mathrm{st}$ rib, and running caudoventrally to the medial surface of shoulder joint. The punctures were done on standing animals.

A. brachialis, is a magistral artery for the free part of the foreleg, it goes obliquely on the medial side of the foreleg towards the craniomedial surface of the elbow and is accompanied by the $v$. brachialis and $n$. medianus (Popesko et al. 1992). Because of its subcutaneous localization, pulsation of the artery could be felt.

A. saphena runs subcutaneously from the distal part of the femoral channel. The artery emerges on medial surface of the thigh and, together with the $n$. saphenus and $v$. saphena, continues to the medial side of the fore-knee. The artery is localized by palpation of its pulsation. Collections of blood from the $a$. brachialis and $a$. saphena were done with the animals in the lateral position.

A. caudalis mediana is localized, together with the vein, in the middle line on ventral tail surface. The punctures were done on standing animals at the level of the 2 nd to 4 th vertebra after raising the tail.

The medial branch of $a$. auricularis caudalis is situated subcutaneously on the dorsal surface of the ear. The artery is clearly visible after cutting or shaving the hairs. The artery runs in the middle of the convex side of the ear, from the base to the tip. Its pulsation could be felt by palpation.

\section{Methods of blood collection}

The blood was collected into heparinized glass capillaries or into $1 \mathrm{ml}$ syringes (Radiometer Copenhagen) designed specially for collection of arterial blood. The blood was collected without sedation and/or local anaesthesia. Puncture sites were chosen by finding the pulsation of the subcutanoeous artery (a. brachialis, a. saphena, a. auricularis caudalis), expected location of the deeper arteries (a. carotis communis, a. axillaris), or by anatomical knowledge of their location (a. caudalis mediana, partly a. carotis communis). The arterial origin of the blood was indicated by its light-red colour, spontaneous outflow (or rhythmic squirts) of the blood, as well as by determined values of blood gases - $\mathrm{pO}_{2}$ and $\mathrm{pCO}_{2}$, and the saturation of haemoglobin by oxygen in the analysed blood samples. Punctures were done with disposable Luer locked needles, size G18 - G22. During the puncture and blood collection we also checked the responses of animals, demands for restraining and handling the animals, as well as the efficiency of the technique. In both calves and dairy cows, the punctures were done with one helper restraining the animal. In dairy cows, the $a$. brachialis and $a$. saphena were not punctured because of the difficult restraint (need for lateral position), which makes these techniques - without sedation or anaesthesia - inconvenient in routine clinical practice. After blood collection, the puncture site was compressed manually for a short time to avoid possible bleeding and the occurrence of haematoma.

\section{Results}

Assessment of blood collections from selected arteries with recorded advantages and disadvantages is presented in Table 1. Rates of successful punctures and arterial blood collections in calves and dairy cows are presented in Table 2.

Both in calves and dairy cows, the best results were recorded for the punctures of $a$. axillaris (Plate VI, Fig. 1) and medial branch of a. auricularis caudalis (Plate VI, Fig. 2). Collections of arterial blood from $a$. caudalis mediana (Plate VII, Fig. 3) were successful 
Table 1

Assessment of various sites and techniques of arterial blood collection in cattle

\begin{tabular}{|c|c|c|}
\hline Site of sampling & Advantages & Disadvantages \\
\hline a. carotis communis & $\begin{array}{l}\text { Sampling in standing animal, palpable } \\
\text { artery pulsation in calves and lean adults, } \\
\text { sometimes possible to fix the artery under } \\
\text { the skin }\end{array}$ & $\begin{array}{l}\text { The artery is located deeper, not directly } \\
\text { under the skin, difficult localization in } \\
\text { adult cattle, better movability and ,loss“ } \\
\text { of the artery - blind puncture }\end{array}$ \\
\hline a. axillaris & $\begin{array}{l}\text { Sampling in standing animal, good } \\
\text { localization in calves and partially in } \\
\text { adults, quite good fixation, only mild } \\
\text { response of animals to sampling }\end{array}$ & $\begin{array}{l}\text { Difficult localization in adult and obese } \\
\text { cattle, possible for blind puncture only }\end{array}$ \\
\hline a. saphena & $\begin{array}{l}\text { Easily palpable pulsation in calves and } \\
\text { adult cattle }\end{array}$ & $\begin{array}{l}\text { Sampling in lateral recumbency, more } \\
\text { demanding fixation - possible effects on } \\
\text { some analysed indices }\end{array}$ \\
\hline a. brachialis & $\begin{array}{l}\text { Possible palpation of pulse waves in } \\
\text { calves }\end{array}$ & $\begin{array}{l}\text { The same as in } a \text {. saphena, useful only in } \\
\text { calves and young cattle up to } 6 \text { months of } \\
\text { age }\end{array}$ \\
\hline a. caudalis mediana & $\begin{array}{l}\text { Sampling in standing animal, less } \\
\text { demanding fixation of animals }\end{array}$ & $\begin{array}{l}\text { Puncture without fixation of the artery, } \\
\text { common course of the artery and vein } \\
\text { giving possibility for collection of mixed } \\
\text { or venous blood }\end{array}$ \\
\hline $\begin{array}{l}\text { a. auricularis caudalis } \\
\text { - medial branch }\end{array}$ & $\begin{array}{l}\text { Sampling in standing animal, good visibility } \\
\text { of the artery, particularly of its medial } \\
\text { branch, less movability, good fixation, less } \\
\text { obvious defence reactions of animals, } \\
\text { possible sampling in calves and cows }\end{array}$ & $\begin{array}{l}\text { Sometimes difficult in calves because of } \\
\text { narrow lumen, cutting or even shaving of } \\
\text { hairs above the artery }\end{array}$ \\
\hline
\end{tabular}

Table 2

Successful arterial punctures and arterial blood collections in calves compared with cows

\begin{tabular}{|l|c|c|c|c|}
\hline Punctured artery & No. of calves & $\begin{array}{c}\text { No. of successful } \\
\text { samplings }\end{array}$ & No. of cows & $\begin{array}{c}\text { No. of successful } \\
\text { samplings }\end{array}$ \\
\hline a. carotis communis & 15 & 8 & 8 & 1 \\
a. axillaris & 73 & 73 & 18 & 14 \\
a. saphena & 5 & 2 & 0 & 4 \\
a. brachialis & 5 & 2 & 0 & 15 \\
a. caudalis mediana & 11 & 5 & 15 & \\
a. auricularis caudalis & 43 & 41 & & \\
- medial branch & & & & \\
\hline
\end{tabular}

only in a small number of animals; frequently we obtained the venous blood. For the puncture of $a$. carotis communis, we recorded a higher rate in calves; this puncture was successful in only one dairy cow. The punctures were done on standing animals and the most obvious responses of animals were observed with the puncture of a. carotis communis. Rates of successful puncture of $a$. saphena (Plate VII, Fig. 4) and $a$. brachialis in calves were quite low. These punctures were done in calves lying in a lateral position, which required more demanding restraint and led to some counteractions by the animals, both before and during the intervention. 
On the basis of the aforementioned results we assume that arterial blood collection from a. axillaris and $a$. auricularis caudalis is the most useful and efficient.

The punctures and blood collections were done with needles of various sizes, lengths, and lumina. With the use of needles with smaller lumina $(22 \mathrm{G}-0.7 \times 35 \mathrm{~mm} ; 21 \mathrm{G}-0.8 \times 40 \mathrm{~mm})$ we obtained small amount of blood, which slowly flowed out. This was enough to fill glass capillaries (volume up to $200 \mu \mathrm{l}$ ) or special plastic self-filling syringes designed for collection of arterial blood. The advantage of these needles is mild traumatization, the avoidance of haematomas, good repeatability, and a reduction in animal responses. With the use of needles with larger lumina (20G-0.9 $\times 40 \mathrm{~mm} ; 18 \mathrm{G}-1.2 \times 40 \mathrm{~mm})$, the blood squirted from the needle and it was possible to obtain larger blood amounts. However, with these needles, we observed intense vessels reactions, the occurrence of haematomas, reduced repeatability and reliability of another collection from the same site, and more intense reactions of the animals to the puncture.

\section{Discussion}

In routine practice, collection of arterial blood in cattle and other species is less frequent. It is mostly used in the monitoring of blood gases, providing direct information about respiratory functions (Adams et al. 1991). Rose and Rosdale (1981) reported that the analysis of arterial blood become has become more frequent in veterinary practice, for example in surgery, and it is attracting more importance in clinical research and diagnosis. Therefore, they emphasise the need for the easy availability of methods of arterial blood collection in veterinary hospitals and laboratories. Regarding the main goal of these methods - assessment of ABB and BG values - these methods should be simple, easy, with minimum demands on handling and restraint of the animals (Muylle et al. 1996). Despite almost the same general opinions about the importance of arterial blood collection and analysis in the evaluation of disorders of $\mathrm{ABB}$ and $\mathrm{BG}$, there are different views on collection methods in relation to the age of the animals (young, adult), position (standing, lying), and puncture site (large central arteries, small peripheral arteries). These aspects may change the values and correlations of the indices, particularly those of blood $\mathrm{pH}$ and blood gases.

Many authors have investigated and verified various sites and techniques of arterial blood collection in cattle. Some of these techniques were used only experimentally with the use of general or local anaesthesia and the vessels' cannulas. However, these methods have not been proved in routine practice, or they were used only occasionally - aorta ascendens (abdominalis) (Uhling and Gorznij 1993), a. carotis communis (Muylle et al. 1996), a. iliaca externa (Vojenčiak and Duran 1978), a. saphena (Donawick und Baue 1968), a. femoralis (Alnoor et al. 1986), a. temporalis superficialis (Becker 1977), a. facialis (Muylle et al. 1996), a. metacarpalis palmaris superficialis III. (Waizenhöfer und Mülling 1978), a. digitalis palmaris communis (Muylle et al. 1996).

Numerous methods reported in the literature evaluated arterial blood collection in newborn calves as not suitable for field practice (Adams et al. 1991). The authors emphasise that $a$. caudalis mediana and $a$. auricularis are too thin and awkwardly located, especially in case of the hypotension and reduced peripheral tissue perfusion. The technique of blood collection from $a$. brachialis reported by Fischer (1956) in standing cattle is also not suitable in lying newborn calves, nor is the puncture of abdominal aorta because of possible contamination and infection of peritoneal cavity, as well as life endangering injury to the aorta. Because it is inconvenient in calves, the aforementioned authors consider also punctures of a. carotis, a. saphena, middle and plantar metatarsal arteries unsuitable. Szenci and Nyiro (1981) consider arterial blood collection in calves under common conditions to be very problematic, even the collection from the navel artery. 
Several authors related values of blood gases to the position of animals during the collection. According to Adams et al. (1991), in calves up to the age three weeks, the most useful method is the direct puncture of $a$. brachialis in the lateral lying position. On the other hand, Stewart et al. (1984) consider this method unsuitable because it may lead to a decrease in $\mathrm{pO}_{2}$ values by up to $4 \mathrm{kPa}$ compared with collection from standing animals. Similar findings in dairy cows were reported by Wagner et al. (1990). Adams et al. (1991) recorded significant changes in BG values in the arterial blood of some calves kept in a lateral position for over 10 min during the blood collection. The authors emphasise that the major disadvantage of their methods of collection is the need to bear the calves down and keep them in the lateral position. Moreover, to obtain the correct values of BG, arterial blood collection should be done as early as possible after achieving the desired position of the animal. According to Muylle et al. (1996) and our experiences, this puncture is also possible in older calves, but restraint is more difficult. Similar experiences are reported about blood collection from $a$. saphena. On the basis of our experiences and results obtained during the collection of blood from $a$. brachialis and $a$. saphena we can confirm that restraint in the lateral position requires increased demands on handling the animals. Calves resent this position, which leads to difficulties in the localization and puncturing of the arteries, despite their subcutaneous location. The aforementioned factors may contribute to false results of blood analysis. Following our experience with calves, we did not collect blood from $a$. brachialis and $a$. saphena of dairy cows.

Several authors consider collection of blood from a. auricularis caudalis useful, reliable, and suitable both in calves and adult cattle (Oakley et al. 1980; Fischer et al. 1980). Rates of successful samplings presented in our work indicate that blood collection from this peripheral artery with a relatively small lumen is possible without any serious problems, both in calves and adult cattle.

Björkman et al. (1992) reported $a$. caudalis mediana as the mostly reported only artery accessible without surgical intervention. Collection of blood from this artery is also described by Gustin et al. (1988) and Collie (1990). Although the tail vein and artery run together at horizontal plane approximately up to the 4th tail vertebra, anatomical studies have shown some variability in the location of these vessels, both in the horizontal and vertical planes (Ghoshal and Getty 1967). Muylle et al. (1996) considered arterial blood collection from $a$. caudalis mediana not reliable because of the frequent collection of venous blood. On the basis of the rates of successful blood collection from the $a$. caudalis mediana we agree with Bien ek et al. (1987), that blood collection attempts from this artery is an easy and quick method with no risk to the animal. However, it frequently leads to collection of venous instead of arterial blood.

While collection of arterial blood from a . axillaris is assessed by Muylle et al. (1996) as not useful because of the difficult finding of the artery, Fischer (1956) considers this method suitable. However, it requires some skill. Our experience and numbers of successful collections confirm its suitability for blood collection, particularly in calves. In older and adult animals, this technique is more demanding or even impossible because of welldeveloped muscles at the site of puncture (Adams et al. 1991).

For the collection of arterial blood in standing cattle, Muylle et al. (1996) also recommend a. carotis communis (besides the medial branch of $a$. auricularis caudalis). Blood collection from this artery is described almost exclusively in connection with surgical relocation of the artery, or after the insertion of a cannula. Fischer (1956) considers the direct puncture of a. carotis communis to be difficult, not reliable, and leading to marked undesirable responses from the animals. Because of good experience with the direct puncture of $a$. carotis communis in horses (Rose and Rosdale 1981), we used this method also in cattle. The data presented of successful collection indicate the possible use of this method in calves. In adult cattle, due 
to the thick muscles and deep location of the artery, the puncture only randomly succeeded, and efficiency rates were much worse than those in the puncture of $a$. axillaris.

The collection and analysis of arterial blood are of improtance in veterinary laboratory diagnosis. In the literature data, there are different opinions on the site and technique of arterial blood collection. Following our experiences with arterial blood collection in 152 calves and 51 dairy cows, in routine practice and the evaluation of acid-base balance and blood gases, we recommend collection from a axillaris and a. auricularis caudalis. After acquiring some skill, we consider these methods to be the most convenient and reliable. Collections of arterial blood from a. carotis communis and a. caudalis mediana are also possible, however, these methods are less efficient because of lower repeatability and low successful rates. Blood collection from these arteries is based on puncture at the place of the expected location of the artery. Punctures of the $a$. brachialis and a. saphena we consider to be the least efficient because of the difficult restraint of calves in the lateral position, possible changes in blood gases values, and low rates of successful sampling.

\section{Výber vhodných artérií na odber krvi u hovädzieho dobytka pre hodnotenie krvných plynov a acidobázickej rovnováhy}

$\mathrm{V}$ práci sme sa zamerali na výber najvhodnejších artérií pre odber krvi sa u teliat a dojníc z aspektu využitia tohto zákroku pre hodnotenie acidobázického stavu a krvných plynov u hovädzieho dobytka. Na základe anatomických poznatkov a literárnych údajov sme na tento účel vybrali 6 centrálnejšie a periférnejšie od srdca prebiehajúcich artérií a. axillaris, a. carotis communis, a. brachialis, a. saphena, a. caudalis mediana a $a$. auricularis caudalis. Odbery arteriálnej krvi sme vykonali a ich úspešnost̉ vyhodnotili celkom u 152 teliat a 51 dojníc. Pozornost pritom bola vzhladom k možným vitálnym vplyvom zo strany zvierat na hodnoty krvných plynov venovaná náročnosti fixácie pri zákroku a minimalizácii stresovania zvierat, sledovali sme zároveň aj reakcie zvierat na zákrok. Dosiahnuté výsledky úspešnosti punkcií artérií poukázali na to, že arteriálnu krv pre daný účel vyšetrení je možné u oboch kategórií zvierat najvhodnejšie a spolahlivo odoberat po získaní praktickej zručnosti predovšetkým z a. axillaris a a. auricularis caudalis. Punkcia a. carotis communis a a. caudalis mediana bola menej úspešná tak $\mathrm{u}$ teliat ako aj dojníc a vzhladom $\mathrm{k}$ väčšej náročnosti zákroku, výraznejších reakcií zvierat, resp. menšej opakovatelnosti odberu sa ukazuje z praktického hladiska ako menej výhodná. Pre nízku úspešnost̉ odberu krvi a zároveň náročnejšiu fixáciu teliat v bočnej polohe s možnostou výraznejšieho ovplyvnenia výsledkov hodnotených parametrov (predovšetkým krvných plynov) sa odber krvi z a. brachialis a a. saphena ukázali pre nás ako najmenej vhodné.

\section{References}

ADAMS, R, HOLLAND, MD, ALDRIDGE, B, GARRY, FB, ODDE, KG 1991: Arterial blood sample collection from the newborn calf. Vet Res Commun 15: 387-394

ALNOOR, SA, SLOCOMBE, RF, DERKSEN, FJ, ROBINSON, NE 1986: Hemodynamic effects of acute pneumonia experimentally induced in newborn calves inoculated with Pasteurella haemolytica. Am J Vet Res 47: $1382-1386$

BECKER, M 1977: Eine Methode des arteriellen Zugangs beim Rind. Schweiz Arch Tierheilk 119: 193-195

BIENEK, K, ALBRYCHT, A, CAKALA, S 1987: Blutgaswerte von Khen in Proben aus den Blutgefassen am Schwanz. Tierarztl Umschau 42: 451-455

BJÖRKMAN, C, FORSLUND, K, HOLTENIUS, P, OLSSON, G, WIKTORSSON, H 1992: A comparative study of arterial and venous blood acetate concentration in cows fed different diets close to parturition. J Vet Med A 39: $548-552$

COLLIE, DDS 1991: Blood gas and acid-base values in calves, sampled from the brachial and coccygeal arteries. Br Vet J 147: 232-237

DONAWICK, WJ, BAUE, AE 1968: Blood gases, acid-base balance, and alveolar-arterial oxygen gradient in calves. Am J Vet Res 29: 561-567 
FISCHER, EW 1956: Arterial puncture in cattle. Vet Rec 68: 691-692

FISCHER, EW, SIBARTIE, D, GRIMSHAW, WTR 1980: A comparison of the $\mathrm{pH}, \mathrm{pCO}_{2}, \mathrm{pO}_{2}$ and total $\mathrm{CO}_{2}$ content in blood from the brachial and caudal auricular arteries in normal cattle. Br Vet J 136: 496-499

GALLAGHER, EJ, RODRIGUEZ, K, TOUGER, M 1997: Agreement between peripheral venous and arterial lactate levels. Annals Emerg Med 29: 479-483

GHOSHAL, NG, GETTY, R 1967: Applied anatomy of the sacrococcygeal region of the ox as related to tailbleeding. Vet Med - Small Anim Clin 62: 255-264

GUSTIN, P, DE GROOTE, A, DHEM, AR, BAKIMA, M, LOMBA, F, LEKEUX, P 1988: A comparison of $\mathrm{pO}_{2}$, $\mathrm{pCO}_{2}, \mathrm{pH}$ and bicarbonate in blood from the carotid and coccygeal arteries of calves. Vet Res Commun 12: $343-$ 346

MUDROŇ, P 1998: Štúdium vitamínu E a lipoperoxidačných procesov u dojníc postihnutých tukovou infiltráciou a insuficienciou pečene. PhD Thesis. Univ Vet Med, Košice, $155 \mathrm{p}$

MUDROŇ, P, REHAGE, J, SCHOLZ, H 1999: Venöse und arterielle Plasma-Ammoniumkonzentrationen von Milchkühen mit Leberinsuffizienz. Proceedings der 2. Fortbildungstatung der Medizinischen Universitätsklinik für Klauentiere der Veterinärmedizinischen Universität Wien „Wiederkäuer und seine Probleme“, Austria, pp. 27-28

MUYLLE, S, ANTHONE, P, SIMOENS, P, LAUWERS, H 1996: Preferential sites for arterial blood sampling in cattle. Vet Rec 139: 86-88

NAGY, O, KOVÁČ, G, SEIDEL, H, WEISSOVÁ, T 2001: The effect of arterial blood sampling sites on blood gases and acid-base balance parameters in calves. Acta Vet Hung 49: 331-340

OAKLEY, GA, JONES, DE, HARRISON, JA, WADE, GE 1980: A new method for obtaining arterial blood samples from cattle. Vet Rec 106: 460

POPESKO, P et al. 1992: Anatómia hospodárskych zvierat. Príroda, Bratislava, 693 p.

ROSE, RJ, ROSSDALE, PD 1981: Techniques and clinical application of arterial blood collection in the horse. Equine Vet J 13: 70-73

SLANINA, L, NAGY, O, ŠEDOVIČ, M, STRUHÁRIKOVÁ, J 1992: Dynamik des Säure-Basen Haushaltes des vensen und arteriellen Blutes bei klinisch gesunden Kälbern. Dtsch Tierarztl Wschr 99: 182-186

SPEIRS, VC 1980: Arteriovenous and arteriocentral venous relationships for $\mathrm{pH}, \mathrm{pCO}_{2}$, and actual bicarbonate in equine blood samples. Am J Vet Res 41: 199-203

STEWART, JH, ROSE, RJ, BARKO, AM 1984: Respiratory studies in foals from birth to 7 days old. Equine Vet J 16: 323-328

SZENCI, O, NYIRO, K 1981: Assessment of the parameters controlling the acid base status of newborn calves. Acta Vet Hung 29: 153-157

UHLING, A, GORZNY, O 1993: Blutgasanalytische Untersuchungen bei lungengesunden Mastkälbern unterschiedlichen Alters. Mh Vet Med 48: 255-259

VOJENČIAK, J, ĎURAN, A 1978: Metóda odberu arteriálnej krvi u hovädzieho dobytka. Vet Med (Praha) 23 : 317-318

WAGNER, AE, MUIR, WW, GROSPITCH, BJ 1990: Cardiopulmonary effects of position in conscious cattle. Am J Vet Res 51: 7-10

WAIZENHÖFER, H, MÜLLING, M 1978: Untersuchungen über das Verhalten von $\mathrm{pH}_{2}, \mathrm{pO}_{2}$ und $\mathrm{pCO}_{2}$ in venösen, kapillären und arteriellen Blut neugeborener Kälber. Berl Münch Tierarztl Wschr 91: 173-176 
Plate VI

Nagy O. et al.: Selection... pp. 289-296

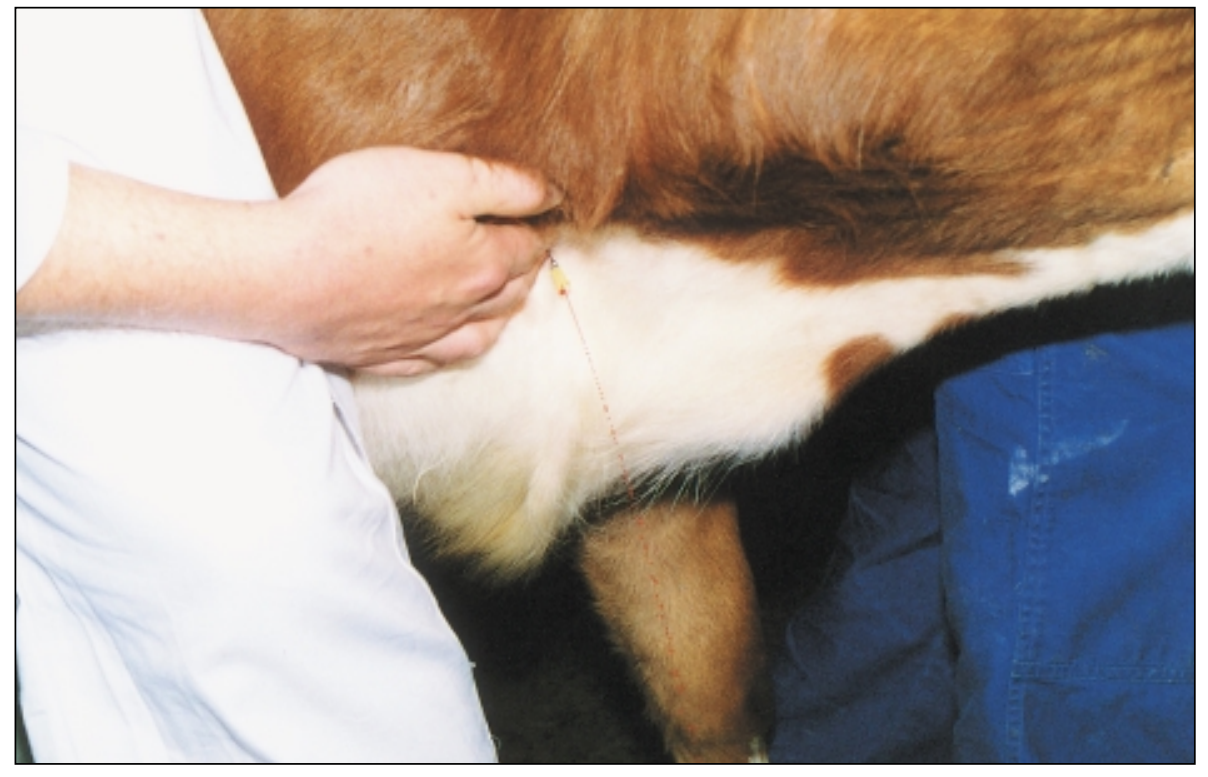

Fig. 1. Puncture of a. axillaris in a 5-month-old calf

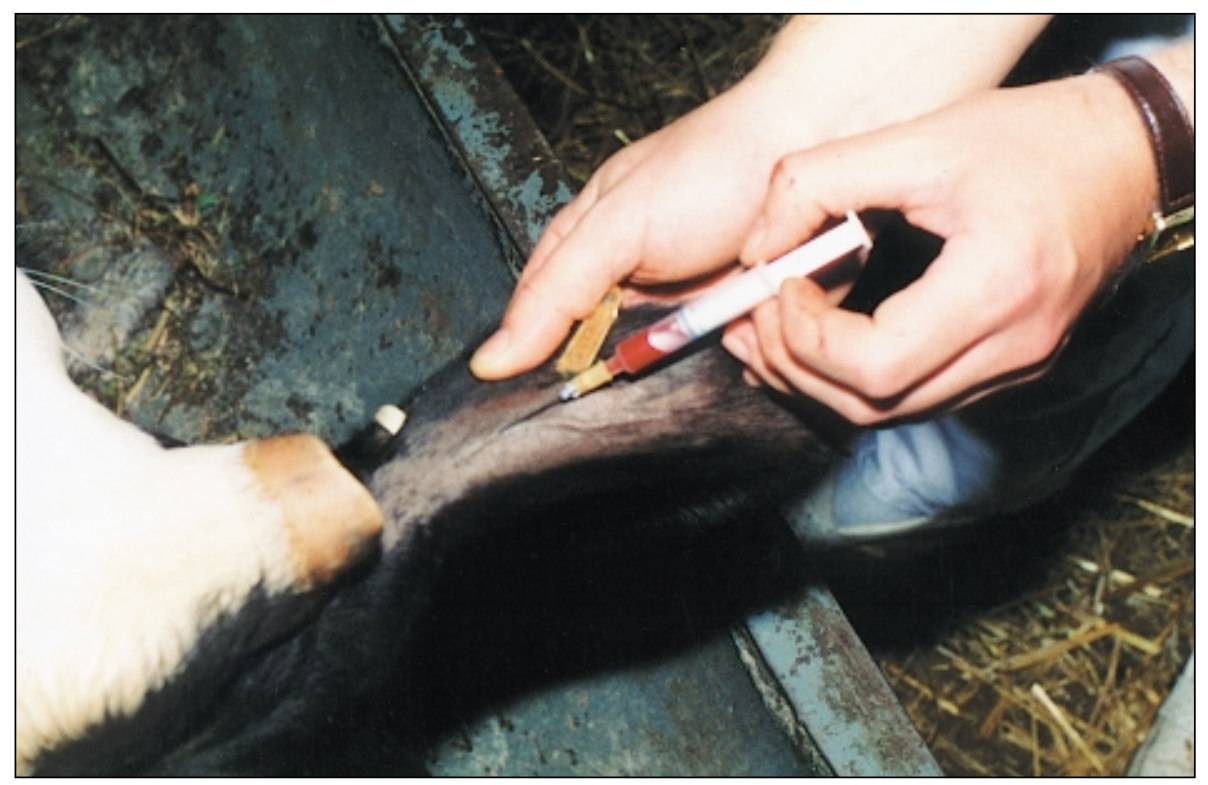

Fig. 2. Puncture of a. auricularis caudalis and arterial blood sampling into the syringe in a cow 
Plate VII

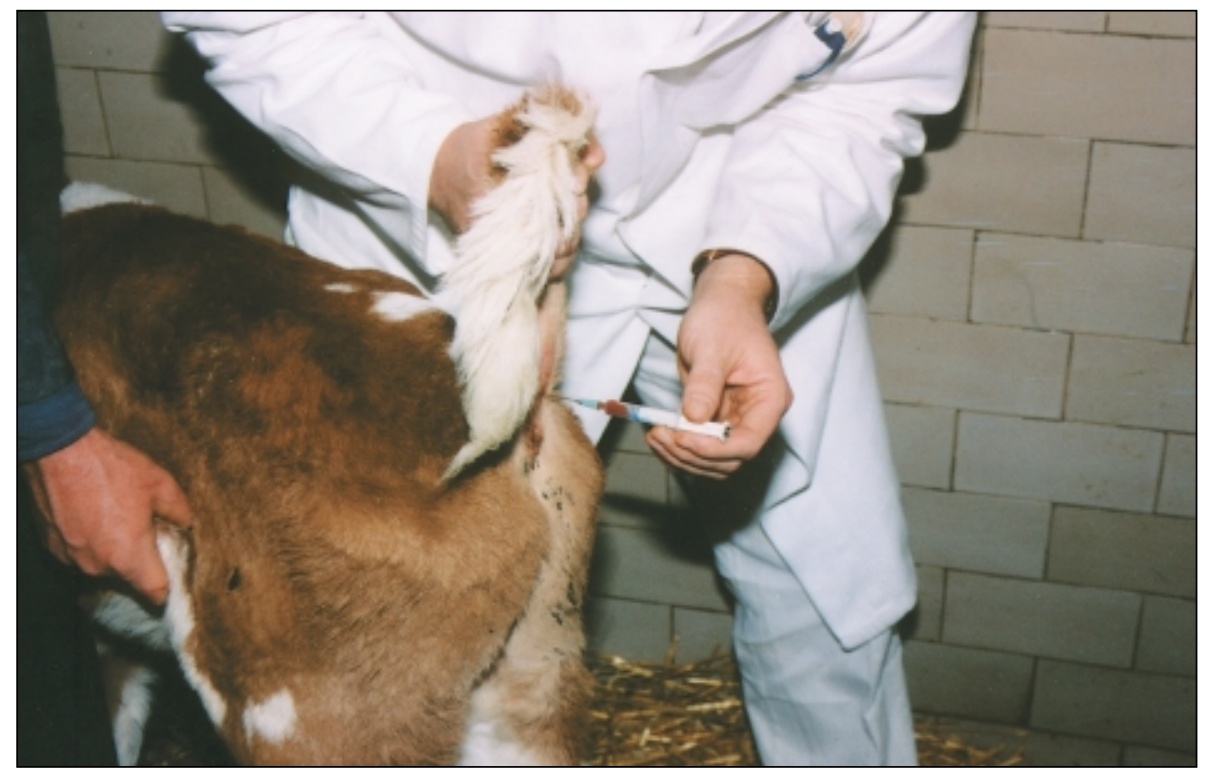

Fig. 3. Puncture of a. coccygea and arterial blood sampling into the syringe in a one-month-old calf

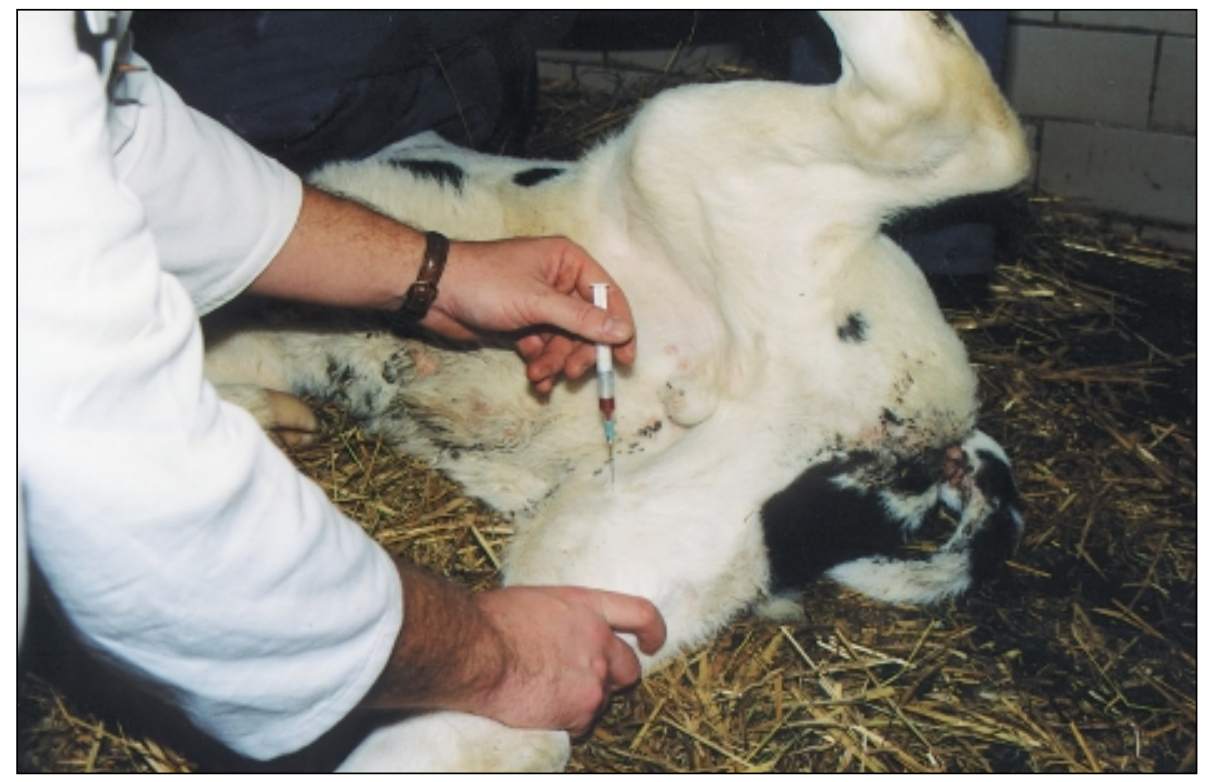

Fig. 4. Puncture of $a$. saphena and arterial blood sampling into the syringe in a one-month-old calf 